\title{
Exploring professional roles for early career engineers: a systematic literature review
}

\author{
Sofie Craps ${ }^{\mathrm{a}}$, Maarten Pinxten ${ }^{\mathrm{a}}$, Heidi Knipprath ${ }^{\mathrm{b}}$ and Greet Langie ${ }^{\mathrm{a}}$ \\ ${ }^{\mathrm{a}}$ Faculty of Engineering Technology, KU Leuven \& Leuven Engineering \& Science Education Centre, Leuven, Belgium; \\ ${ }^{b}$ Research Institute forWork and Society, KU Leuven, Leuven, Belgium
}

To cite this article: Sofie Craps, Maarten Pinxten, Heidi Knipprath \& Greet Langie (2020): Exploring professional roles for early career engineers: a systematic literature review, European Journal of Engineering Education, DOI: 10.1080/03043797.2020.1781062

\begin{abstract}
It is recognised that engineers end up in a wide variety of engineering positions and that the importance of professional competencies might vary accordingly. However, most studies regarding professional competencies, employability or career guidance fail to address this variety in professional roles. This systematic literature review aims to identify professional roles for early career engineers and explores the defining attributes. Twentyfour publications were selected for inclusion by screening and appraising results obtained from three databases. Three frameworks that fulfilled the analysing criteria described similar roles focusing on innovation, optimisation and customisation. The majority of studies investigated professional competencies as identifying attributes, but inconsistency in and a lack of definitions hindered to determine the distinct professional competencies per role. Further research is recommended to identify role attributes and to investigate how a professional roles framework can support career development in engineering education, more particular in creating professional and self-awareness.
\end{abstract}

\section{KEYWORDS}

employability; professional skills; skills mismatch; job-fit; career guidance; systematic review

\section{CONTACT}

Sofie Craps, sofie.craps@kuleuven.be

\section{Introduction}

Nowadays, employees have to take a more flexible and proactive approach to their working lives, involving the continuous management of their own employability, to meet the challenges of a global economy characterised by rapid change (Tomlinson 2007). Higher education institutions increasingly acknowledge their responsibility to guide students, both in their academic growth and in their career development (Burke et al. 2017; National Academy of Engineering 2018). Consequently, the educational field is challenged to explicitly trigger students' reflection on their professional future.

\subsection{Narrow view on engineering}

In engineering education, students' perceptions of their professional future is a focus that deserves due attention. Research indicates that, even close to graduation, many engineering students remain 
uncertain about what engineering is and what engineers do (Bennett and Male 2017; Lichtenstein et al. 2009; Matusovich et al. 2009). Moreover, some students predominantly consider engineering education and practice as primarily technical, and hold narrow perceptions of the professional aspects of engineering (Brunhaver et al. 2018).

\subsection{Mismatch}

These narrow future perceptions lead to a gap between the graduates' expectations and their actual experiences (Chan, Zhao, and Luk 2017; Watson and Meiksins 1991) with significant negative correlations to job satisfaction (Jusoh, Simun, and Chong 2011). Employers, regardless of the field, also refer to this mismatch, indicating that there is still a skills gap and that they experience difficulties in finding graduates with the right set of competencies or the required competency level (IET 2016; Mourshed, Patel, and Suder 2014). The European report 'Education to Employment' (2014) documented a particular shortage of non-technical skills, such as communication skills, lifelong learning, teamwork skills, creativity or problem solving - further in this paper described as professional competencies. For many years now, there has been a general agreement on the importance of these competencies in engineering education (ABET 2017; ENAEE 2015; Murphy et al. 2016; National Academy of Engineering 2004), but it is also clear that the employability debate goes beyond devel- oping competencies. It also involves identity development (Tomlinson 2007).

\subsection{Lack of reflection}

Constructing a professional identity requires the ability to critically reflect on one's thoughts and prior achievement, but also the ability to articulate one's future aspirations in the engineering profession. The latter aspect presumes more awareness and a more realistic understanding of the engineering work and the competencies required (Yorke and Knight 2006). In response, engineering education has been adapting its learning methods. Interventions to expose students to authentic engineering experiences, for example in problem-based learning, are commonly used in engineering education, but the link to the engineering practice is not always clear (Bennett and Male 2017; Tymon 2013). Aspects like one's beliefs and values are rarely included in engineering educational activities which makes it difficult for students to construct an engineering identity (Morelock 2017).

Several theories for career development, investigating the process and content by which a career identity is formed, underline the importance of awareness of both personality (e.g. interests, strengths and weaknesses) and future career opportunities (Bridgstock 2009; Brown and Hirschi 2013; Eccles 2011; Holland 1997; Oyserman et al. 2004) as more congruency between personality and career leads to increased employability, greater job satisfaction and success (Gottfredson and Johnstun 2009; Holland 1997; Yorke and Knight 2006). The reasoning implies the premise that students have enough information about (a) their own competencies, preferences and personality and (b) the educational, training or job requirements (Bimrose et al. 2004).

It is recognised that there are different types of engineers - Nilsson (2010) suggests to use the concept of professional roles - and that the importance of professional competencies or the way engineers create value varies across job tasks and work contexts (Male, Bush, and Chapman 2011; Nilsson 2010; Trevelyan and Williams 2018). For example, an engineer working in an R\&D department might need other competencies than an engineer working in maintenance. However, frameworks 
describing professional roles for engineers appear to be underexposed in the current literature.

\subsection{Purpose of this study}

This work contributes to the pivotal role of professional identity development in that it explores frameworks that can support career guidance of engineering students based on the needs of the professional field. Such frameworks might be valuable instruments to increase students' awareness of the engineering practice, and foster reflection of the future self. As the early career experiences are a major influence on individuals' career decisions, which affect their well-being, career development, and continuance in a profession (Korte, Brunhaver, and Zehr 2019), this study focuses on professional roles for early career engineers in particular. However, this article can also be a potential resource for research on career development in any stage of the engineering career.

The paper is organised as follows. First, we explore the concept of professional roles in different fields. The research methodology is concerned in the second section as well as a description of the included papers of the systematic literature review. Section three analyses the results including an in-depth analysis of the studies that fulfilled all analysis criteria. To conclude, we discuss the results and draw out recommendations for further research.

\section{Professional role}

The term 'role' comes from a world that has nothing to do with engineering: theatre. Actors' scripts were written on rolls of parchment in seventeenth-century France, and 'rôle' became shorthand for the set of actions and the character the actor was supposed to portray. Nobody expected actors to really be the persona of the play, but as 'professionals' they had to be able to fill their role and suspend disbelief in their audience (Paulsen 2011).

Today, the term role evolved to a concept used to guide ideals and expectations of what to be and how to behave - think about gender-roles, age-roles and, in this study, professional roles. As such, professional roles belong to distinct professions, to groups of people who perform activities that are clearly distinguishable from other types of work. They are a cluster of more or less stringent expectations of a person in a certain position, and of what is demanded from this person by members of his or her working environment (De Jager and Mok 1999; Lunenberg, Dengerink, and Korthagen 2014; Paulsen 2011).

When describing six roles for teachers, (Lunenberg, Dengerink, and Korthagen 2014) have pointed out that the concept of professional roles mainly focuses on position and expectations from the environment whereas the concept of professional identity mainly focuses on personal views and self-images. Despite an inconsistent use of terminology and a variance in explicit and abstract definitions, the researchers could identify different roles for teachers (teacher of teachers, coach, researcher, gatekeeper etc.) and define the critical features and role behaviours.

In their international study on journalism competencies, Willnat, Weaver, and Choi (2013) argue that different views on professional roles have implications for competencies. For example, investigative reporting will be more necessary for a journalist in a critical watchdog role than in a neutral disseminator role. Of course, there will be some overlap in competencies needed to perform the different roles well. Another example in this regard is the CanMEDS framework, an internationally recognised framework in the field of medicine, that identifies and describes the 
competencies required for physicians to effectively meet the health care needs of the people they serve, thematically grouped under seven professional roles (Frank, Snell, and Sherbino 2015). For example, in the role of a communicator, a physician aims to facilitate the gathering and sharing of essential information for health care. Therefore, active listening and empathy with patients and their families are crucial competencies. For physicians in a role of health advocates, who work predominantly with communities or patient populations to improve health, competencies as continuing quality improvement and responsibility in using their position and influence are very important.

In the context of engineering, literature on professional roles is scarce. Several terms such as (professional) profiles (Kubler and Forbes 2004; Lima et al. 2017) or sub-occupations (Brunhaver et al. 2013) are also mentioned, but a clear definition of the concept is often lacking. However, like in other fields, it is generally recognised that different types of jobs are associated with different demands and that the professional role is relevant for explaining the importance of professional competencies (Male, Bush, and Chapman 2011; Nilsson 2010). Brunhaver et al. (2013) refer to the significant limitation of one rather generic role for engineers since this requires the same balance of the same technical and professional competencies for all engineers. Nevertheless, most studies regarding professional competencies, employability or career guidance fail to address this variety in professional roles.

Following Lunenberg, Dengerink, and Korthagen $(2014,6)$, in this review study we define the concept professional role as an interpretation of a position based on expectations from the environment. In particular, we will focus on what the work field expects from early career engineers and what attributes are required to fulfil the position in a particular role successfully. As such, a professional roles framework can be a valuable instrument in professional identity development as it involves interaction between the expectations related to a specific professional role (from the work field) and the needs and aptitudes to prepare for that role (of the student) (Becker and Carper 1956). To that end, we set out to address two research questions:

RQ1 'What professional roles for early career engineers can be identified?'

RQ2 'What attributes define the professional roles for early career engineers?'

\section{Method}

A systematic literature review was performed, as it is the best method to identify, appraise and synthesise all the relevant studies on professional roles. We followed the recommendations and methodologies from previous literature reviews in the fields of engineering education and social sciences (Borrego, Foster, and Froyd 2014; Petticrew and Roberts 2006). In this section, we first describe the selected databases, search terms and inclusion criteria before elaborating on the analysis criteria. Third, we will provide a description of the included papers.

\subsection{Databases and search terms}

A systematic literature review was performed in September 2018. An appropriate set of complementary databases was selected to get extensive and broad coverage of the literature in education research in order to increase the probability of finding highly relevant articles: Web of 
Science, Scopus and ERIC - the Educational Resources Information Centre. Based on the background literature and after revision and feedback of the four researchers, the search term 'engineer' was combined with one of the terms:

- role, profile, classification, function, value, expectation

- career, career path, career guidance, career development, career management

The search resulted in 952 potentially relevant studies.

\subsection{Inclusion criteria}

The aim of this research is to look for frameworks that can support career guidance of engineering students based on actual and future needs of the professional field. Therefore, recent studies are of particular interest. We noticed an increasing number of studies since 2008 . Moreover, almost $68 \%$ of the studies were published in the last decade, so we decided to focus the review on the period between 2008 and 2018 resulting in 645 studies (Figure 1).

The titles and abstracts of peer reviewed articles and book chapters written in English were screened. As the topic is underexposed in literature, peer reviewed conference proceedings were included also. Further screening discarded studies on gender roles, on the attractiveness or on persistence in STEM programs in middle or high schools, as well as studies focused on career shifts unless they explicitly described the starting point of this path addressing young graduates at the beginning of a career.

The quality of the papers were appraised and assessed after which papers were excluded that seemed not methodologically sound (reliability, validity). Additionally, a snowball approach was used to identify other relevant studies that had not shown up in the systematic literature search. This added 7 more papers to the collection. We ultimately identified 24 unique studies for further analysis. The search track of exclusion/inclusion is tabulated in Figure 1. 


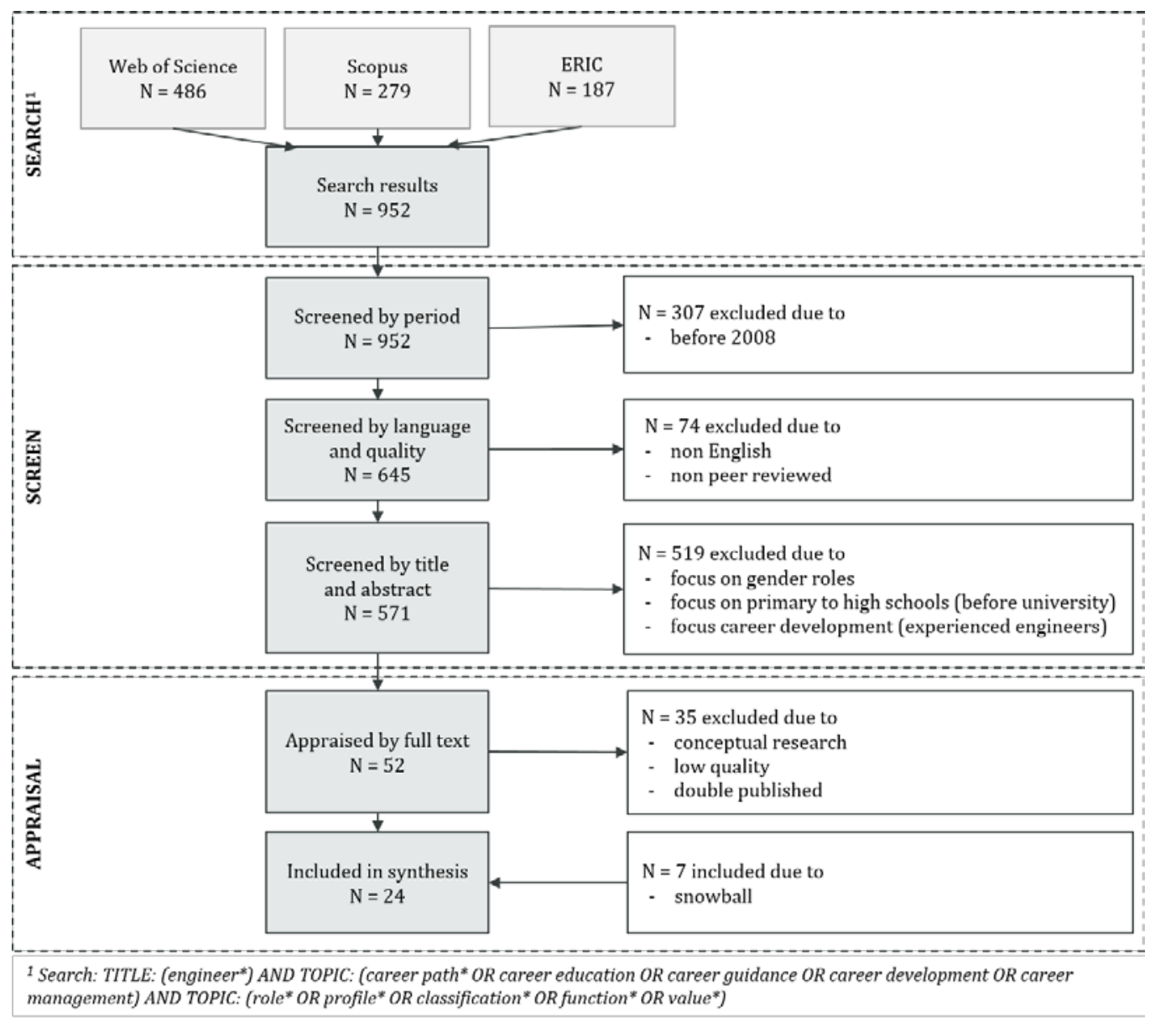

Figure 1. Flowchart of filtering process and results

\subsection{Analysis criteria}

The previous section emphasised on the importance of creating awareness of both personality and future career opportunities when addressing the skills and expectations gaps. For example, engineering students should be aware of the fact that different (early career) jobs require different professional competencies, but also be aware of their strengths and weaknesses regarding these competencies.

The reasoning above was converted into three analysis criteria, in particular, whether the studies were:

(a) applicable to engineering graduates, entering the labour market (expectation management)

(b) applicable to different disciplines or fields (to expand the traditionally narrow focus beyond learning technical and scientific knowledge)

(c) involve different stakeholders from the professional field and higher education (bridging the gaps)

\subsection{Description of the included publications}

In order to describe the 24 publications, the studies are first are classified by terminology related to the concept of professional role. Second, we describe whether developing a framework was a research objective. The descriptive items are included in Table 1. 


\begin{tabular}{|c|c|c|c|c|c|c|c|c|c|c|c|c|c|}
\hline \multirow[t]{2}{*}{ Studies } & \multicolumn{2}{|r|}{ Roles } & \multirow[t]{2}{*}{ Terminology } & \multirow{2}{*}{$\begin{array}{l}\text { Framework } \\
\text { as } \\
\text { research } \\
\text { objective }\end{array}$} & \multirow{2}{*}{$\begin{array}{l}\text { Focus on } \\
\text { early } \\
\text { career }\end{array}$} & \multicolumn{2}{|c|}{ Domain } & \multicolumn{2}{|c|}{ Stakeholders } & \multicolumn{4}{|c|}{ Key elements } \\
\hline & $\begin{array}{l:}\widehat{z} \\
\frac{\tilde{y}}{2}\end{array}$ & $\frac{\mathscr{y}}{\grave{0}}$ & & & & 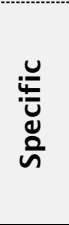 & 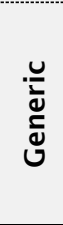 & 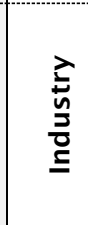 & 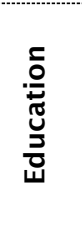 & 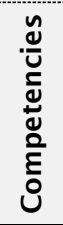 & 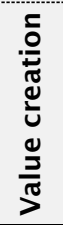 & 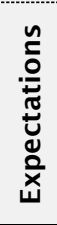 & 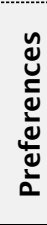 \\
\hline $\begin{array}{l}\text { Gemme and Gingras } \\
(2012)\end{array}$ & \multirow{5}{*}{2} & academic, non-academic & $\begin{array}{c}\text { Career } \\
\text { preference }\end{array}$ & & & $\bullet$ & & & $\bullet$ & & & & $\bullet$ \\
\hline Sinche et al. (2017) & & research-intensive, non-research-intensive & Career trajectory & & & $\bullet$ & & $\bullet$ & & $\bullet$ & & & \\
\hline Betz (2014) & & \multirow{3}{*}{ technical specialist, (project) management } & Profile & & & & $\bullet$ & $\bullet$ & & $\bullet$ & & & \\
\hline $\begin{array}{l}\text { Hodgson, Paton and } \\
\text { Cicmil }(2011)\end{array}$ & & & Role & & & & $\bullet$ & $\bullet$ & & & & $\bullet$ & \\
\hline $\begin{array}{l}\text { Saunders-Smits and De } \\
\text { Graaff }(2012)\end{array}$ & & & Career path & & & $\bullet$ & & $\bullet$ & & $\bullet$ & & & \\
\hline Brunhaver et al. (2013) & \multirow{6}{*}{3} & $\begin{array}{l}\text { engineering practitioners, consultants, } \\
\text { managers }\end{array}$ & Sub-occupations & $\bullet$ & $\bullet$ & & $\bullet$ & $\bullet$ & & $\bullet$ & & & \\
\hline $\begin{array}{l}\text { De Norre, Pinxten, and } \\
\text { Langie }(2016)\end{array}$ & & \multirow{2}{*}{$\begin{array}{l}\text { operational excellence, product leadership, } \\
\text { customer intimacy }\end{array}$} & Role & & $\bullet$ & & - & & $\bullet$ & & & & $\bullet$ \\
\hline Hofland et al. (2015) & & & Role & $\bullet$ & $\bullet$ & & $\bullet$ & $\bullet$ & & $\bullet$ & & & \\
\hline $\begin{array}{l}\text { Gerwel Proches, Chelin } \\
\text { and Rouvrais (2018) }\end{array}$ & & technical, entrepreneurial, management & $\begin{array}{l}\text { Professional } \\
\text { path }\end{array}$ & & $\bullet$ & & - & & $\bullet$ & & & $\bullet$ & \\
\hline $\begin{array}{l}\text { Spinks, Silburn, and } \\
\text { Birchall (2007) }\end{array}$ & & specialist, change agent, integrators & Role & $\bullet$ & $\bullet$ & & $\bullet$ & $\bullet$ & & $\bullet$ & & & \\
\hline Wilcox (2015) & & inventor, consultant, entrepreneur & Role & $\bullet$ & & $\bullet$ & & & & & & & \\
\hline $\begin{array}{l}\text { Bignon and Szajnfarber } \\
(2015)\end{array}$ & \multirow{3}{*}{4} & $\begin{array}{l}\text { enablers, bridgers, researchers and } \\
\text { intrapreneurs }\end{array}$ & Work identities & $\bullet$ & & $\bullet$ & & $\bullet$ & & & & & $\bullet$ \\
\hline $\begin{array}{l}\text { Kamp and Klaassen } \\
(2016)\end{array}$ & & $\begin{array}{l}\text { specialist, front-end innovator, integrator, } \\
\text { contextual engineer }\end{array}$ & Role & $\bullet$ & $\bullet$ & & $\bullet$ & & $\bullet$ & $\bullet$ & & & \\
\hline $\begin{array}{l}\text { Van der Heijden, } \\
\text { Brinkman, and During } \\
(2009)\end{array}$ & & $\begin{array}{l}\text { personal firm or life style entrepreneur path, } \\
\text { professional entrepreneur path, managerial } \\
\text { growth path, entrepreneurial growth path }\end{array}$ & Career Type & $\bullet$ & $\bullet$ & $\bullet$ & & $\bullet$ & & $\bullet$ & & & \\
\hline $\begin{array}{l}\text { Choudhary and Jesiek } \\
\text { (2015) }\end{array}$ & \multirow{2}{*}{5} & $\begin{array}{l}\text { faculty job with focus on research, faculty } \\
\text { job with focus on teaching, industry job with } \\
\text { focus on research, government job with } \\
\text { focus on research, job as an entrepreneur }\end{array}$ & Career path & & $\bullet$ & $\bullet$ & & & • & & & & $\bullet$ \\
\hline Fernandez-Sanz (2010) & & $\begin{array}{l}\text { programmer, analyst, system technician, } \\
\text { consultant, CIO or similar management } \\
\text { positions }\end{array}$ & Positions & & & - & & & $\bullet$ & $\bullet$ & & & \\
\hline
\end{tabular}


Kinoshita, Young, and Knight (2015)

Srour et al. (2013)



Itani and Srour (2016)

\begin{tabular}{c|}
\hline \\
\hline
\end{tabular}

Lauwers, Bonte, and Vanmaercke (2013)

-

8

Medina et al. (2018)



Kinunnen et al. (2018)

Trevelyan and Williams (2018)

Smith, McClelland, and

Smith (2017) technical, supervisory, consultant, nontechnical, other (e.g. academics)

Project Controls Manager, Project Management Track Position, Entry Level

Technical Position, Medium Level Technical

Position, Senior Level Technical Position

technical engineer, technical and

administrative engineer, general or

nontechnical consultant, consultant in the

technical field, opportunity involving

management or supervisory training, job

rotation program (position will be

determined at a later stage)

product, process and automation engineer; maintenance engineer; quality -, preventionenvironment- and safety engineer; project

engineer; R\&D engineer; planning and work

preparation engineer, method engineer;

commercial enginee

Project Management (PM); Production,

Distribution and Logistics (PDL);

Manufacturing and Process Engineering

(M\&PE); Supply Chain Management (SCM)

Ergonomics and Human Factors (EHF);

Strategic Planning (SP) and Financial

Engineering (FE)

Software designer, project manager,

entrepreneur, programmer, administrator,

solving societal problems, researcher,

No roles defined, 14 ways of value creation

in enterprises

5 No roles defined, but 15 responsibilities on

Corporate Social Responsibility
Job function

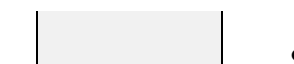

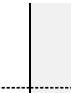

Career path

Job preference

$\bullet$

Profile

Profile

Role

Role

Professions /

Job duties

Role

Role

Role

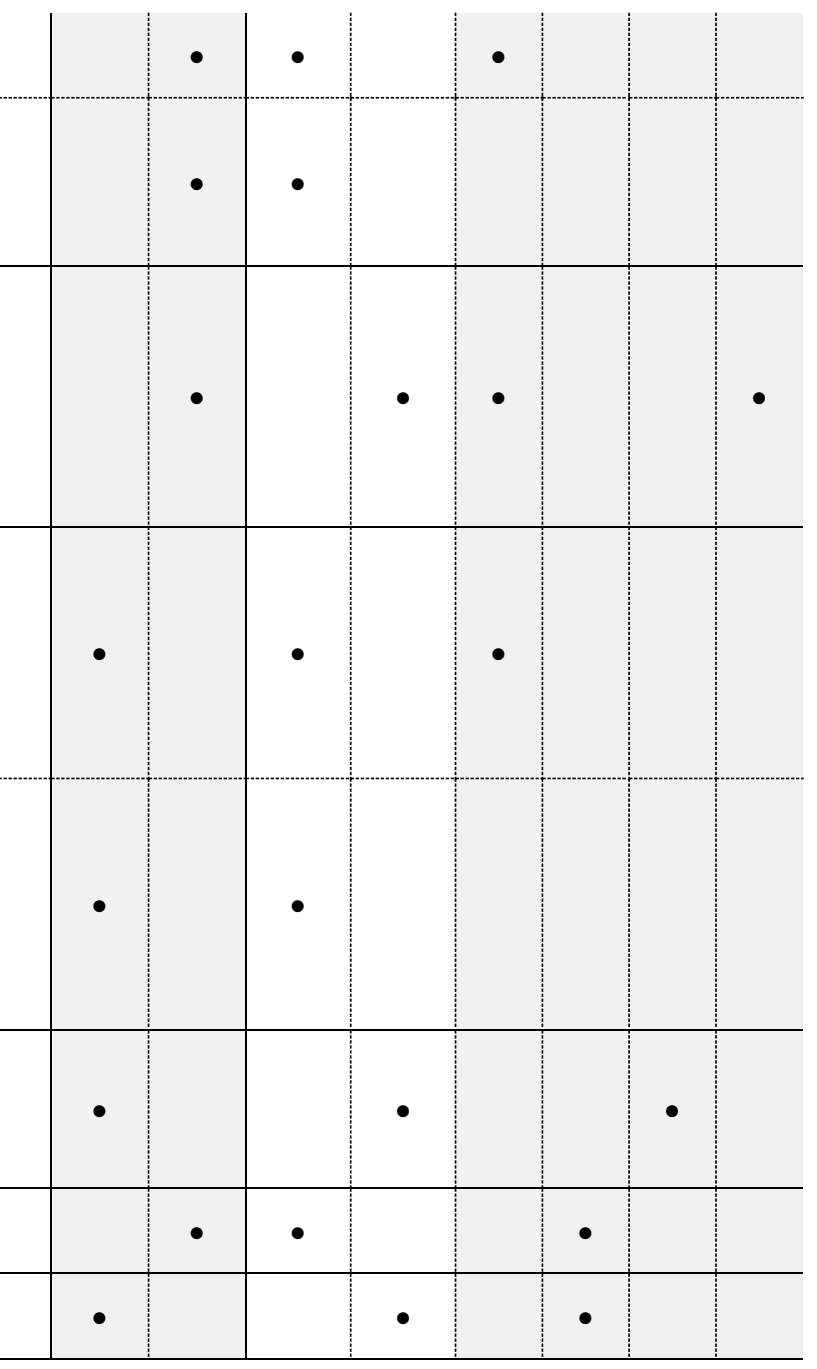




\subsubsection{Terminology related to the professional role concept}

Eleven different terms were found for concepts that could categorise engineers in the work field (Table 1, column 4). 'Roles' (roles or job roles) was used most often $(N=9)$, followed by 'career paths' or 'career trajectories' $(N=5)$, 'profiles' $(N=2)$ and 'job or career preferences' $(N=2)$. Other terms appeared in only one study each, such as 'career types', 'sub-occupations', 'positions', 'professions', 'job functions' or 'work identities'.

Only six studies described the concept they used as overarching classifications, addressing professional competencies (Hofland et al. 2015; Kamp and Klaassen 2016; Spinks, Silburn, and Birchall 2007) or motives and preferences (Bignon and Szajnfarber 2015; Itani and Srour 2016). Wilcox $(2015,1)$ was the only author that explicitly defined the role concept in her study, namely: 'Roles do not necessarily represent formal titles, but identity-related roles that can signify the motives with which [people] engage [in their work]' . This definition is more related to what Lunenberg, Dengerink, and Korthagen (2014) describes as professional identity and less to the expectations of the environment.

\subsubsection{Research objective and methodologies}

In most studies $(N=16)$ engineering categorisations were predominantly used as a framework to elaborate on a specific topic like career preferences. For 10 out of 16 studies, developing a framework or categorisation was an explicit objective (Table 1, column 5). The latter frameworks were developed mostly based on mixed research methods. Interviews were used as a ground theory method to construct the categories and paired with a subsequent survey of engineers or company representatives (e.g. Brunhaver et al. 2013; Hofland et al. 2015; Spinks, Silburn, and Birchall 2007). In other studies, interviews were used to refine a framework based on vacancy analyses (Lauwers, Bonte, and Vanmaercke 2013) or role play (Smith, McClelland, and Smith 2017). Two frameworks were based on a literature (Trevelyan and Williams 2018; Wilcox 2015). Trevelyan and Williams performed a content analysis of data from earlier studies. Finally, one study conducted a design thinking method where a panel discussed what engineering students' competencies should be in 2030 (Kamp and Klaassen 2016).

Although the studies aiming to develop a framework applicable to different engineering disciplines are of particular interest in our research, the other studies will be included in the analysis, as they can provide interesting insights into the study. By consequence, some studies will be discussed more in depth than others.

\section{Results}

An in-depth exploration of the 24 studies would go beyond the scope of this study. An overview of the details of the different studies is presented in Table 1. In the following paragraphs, we will elaborate on the most promising models according to the analysis criteria. We first examined the different roles in the studies; more specifically how many roles were included and how were they described (RQ1). The three analysis criteria (focus on young engineering graduates, independent of discipline and involving different stakeholders) were the guiding principle. Second, we examined which attributes identified the different roles (RQ2). 


\subsection{What professional roles for early career engineers can be identified? (RQ1)}

The studies used a wide range of frameworks consisting of two to fifteen roles or ways to categorise different types of engineers. More than half of the studies described frameworks including two roles $(N=5)$, three roles $(N=6)$, or four roles $(N=3)$. Although different labels were used, we will systematically use the term 'roles' when referring to the different types of engineers in the work field.

\subsubsection{Focus on early career engineers}

Thirteen of the included studies specifically focused on early career engineers (Table 1, column 6). Other studies included frameworks that might also be applicable to young graduates as they do not explicitly refer to work experience (e.g. Bignon and Szajnfarber 2015; Fernandez-Sanz 2010; Kinnunen et al. 2018; Wilcox 2015). These studies agree that a more elaborate categorisation is needed for better engineering education or career development. When investigating career paths or tracks in career development, it can be noticed that there is only a differentiation in roles when progressing in the careers. For example, engineers can develop into a technical expert role or a managerial role (Betz 2014; Hodgson, Paton, and Cicmil 2011; Saunders-Smits and De Graaff 2012). However, these studies identified different professional competencies for the future professional roles that affect the professional success.

\subsubsection{Independent of disciplines}

Half of the studies focused on a specific engineering domain $(N=12)$, the other half focused on the broad field of engineering ( $N=12$ ) (Table 1, column 7 and 8 ).

A specific engineering domain could be a specific engineering discipline, for example, aerospace (Saunders-Smits and De Graaff 2012), ICT (Fernandez-Sanz 2010; Kinnunen et al. 2018), electromechanical or industrial engineering (Lauwers, Bonte, and Vanmaercke 2013; Medina et al. 2018). It could also be a particular area, such as research and academia (Choudhary and Jesiek 2015; Gemme and Gingras 2012; Sinche et al. 2017; Wilcox 2015), entrepreneurship (Van der Heijden, Brinkman, and During 2009) or corporate social responsibility (Smith, McClelland, and Smith 2017) (Table 1, column 3 and 7). Some of these studies, like Saunders-Smits and De Graaff (2012) or Wilcox (2015) described professional roles that were not bound to the discipline and the categories reoccurred in more generic studies. However, often the specific focus was reflected in the professional roles, which hindered transferring the roles to other domains. For example, FernandezSanz (2010) identified six roles for IT engineers, like programmer, analyst, system technician, etc. In their research on potential career paths of doctoral students, Choudhary and Jesiek (2015) distinguished three focuses: research (in faculty, industry or government job), teaching (in faculty) or entrepreneurship. Although the latter construct is not necessarily bound by one specific discipline, the framework for doctoral engineers does not cover all engineering professions.

Studies identifying professional roles independent of discipline seemed to address quiet similar models, but varied in how detailed the roles were conceived (Table 1, column 3 and 8). For example, Brunhaver et al. (2013) categorised engineers in practitioners, managers and consultants, whereas 
Gerwel Proches, Chelin, and Rouvrais (2018) identified technical, management and entrepreneurial roles. Itani and Srour (2016) referred to the entrepreneurial role more precise as general non- technical consultants and consultants in the technical field. Kinoshita, Young, and Knight (2015) also included a category other (e.g. academics). Although the authors did not give clear definitions for each role, it can be argued that these roles can be applied to different engineering domains or disciplines.

An in-depth comparison of the frameworks was bounded by the fact that only three 'generic' frameworks applicable to early career engineers included well-described definitions of the identified roles (De Norre, Pinxten, and Langie 2016; Hofland et al. 2015; Kamp and Klaassen 2016; Spinks, Silburn, and Birchall 2007) (see Table 2 for full definitions). The three frameworks defined the roles by describing the different expectations related to operating in the work environment. Although they were categorised and labelled differently, three similar roles occurred: one role focusing on advancing and optimising technology which requires technical expertise (operational excellence, specialist), the second role focusing on innovation and developing new products (product leadership, change agent, specialist, front-end innovator), a third role focusing on the needs of the customer in different environments (customer intimacy, integrator, system integrator).

Table 2. Overarching models with well-defined professional roles.

\begin{tabular}{|c|c|c|c|c|}
\hline Study & Role 1 & Role 2 & Role 3 & Role 4 \\
\hline $\begin{array}{l}\text { Hofland et } \\
\text { al. (2015) } \\
\text { De Norre, } \\
\text { Pinxten, and } \\
\text { Langie } \\
(2016)\end{array}$ & $\begin{array}{l}\text { Operational } \\
\text { Excellence } \\
\text { organises and } \\
\text { optimises processes } \\
\text { focus on process } \\
\text { efficiency and finding } \\
\text { ways to achieving the } \\
\text { best total cost }\end{array}$ & $\begin{array}{l}\text { Product Leadership } \\
\text { develops new } \\
\text { products/ } \\
\text { technologies } \\
\text { focus on new ideas } \\
\text { and developing the } \\
\text { best product }\end{array}$ & $\begin{array}{l}\text { Customer Intimacy } \\
\text { provides solutions } \\
\text { according to the } \\
\text { needs of the } \\
\text { customer } \\
\text { focus on the best } \\
\text { total solution for } \\
\text { customers }\end{array}$ & \\
\hline $\begin{array}{l}\text { Spinks, } \\
\text { Silburn, and } \\
\text { Birchall } \\
(2007)\end{array}$ & $\begin{array}{l}\text { Specialist } \\
\text { recognises the } \\
\text { continued need for } \\
\text { engineers who are } \\
\text { technical experts of } \\
\text { world-class standing }\end{array}$ & $\begin{array}{l}\text { Change agent } \\
\text { provides the } \\
\text { creativity, innovation } \\
\text { and leadership to } \\
\text { shape the industry in } \\
\text { an uncertain future. }\end{array}$ & $\begin{array}{l}\text { Integrator } \\
\text { operates and } \\
\text { manages across } \\
\text { boundaries, be they } \\
\text { technical or } \\
\text { organisational in a } \\
\text { complex business } \\
\text { environment }\end{array}$ & \\
\hline $\begin{array}{l}\text { Kamp and } \\
\text { Klaassen } \\
(2016)\end{array}$ & $\begin{array}{l}\text { Specialist } \\
\text { advances and } \\
\text { optimises technology } \\
\text { for innovations and } \\
\text { better performance } \\
\text { using scientific } \\
\text { knowledge }\end{array}$ & $\begin{array}{l}\text { Front-end Innovator } \\
\text { advances and apply } \\
\text { knowledge and uses } \\
\text { technology to } \\
\text { develop new } \\
\text { products for the } \\
\text { benefit of people }\end{array}$ & $\begin{array}{l}\text { System Integrator } \\
\text { brings together } \\
\text { disciplines, products } \\
\text { or subsystems into a } \\
\text { functioning whole } \\
\text { that meets the needs } \\
\text { of the customer }\end{array}$ & $\begin{array}{l}\text { Contextual Engineer } \\
\text { exploits diversity-in- } \\
\text { thought to advance } \\
\text { and apply knowledge } \\
\text { and uses technology } \\
\text { in different realms to } \\
\text { develop products and } \\
\text { processes for the } \\
\text { benefit of people in } \\
\text { different cultures and } \\
\text { context }\end{array}$ \\
\hline
\end{tabular}

Kamp and Klaassen (2016) included a fourth role: the contextual engineer who understands complex societal, cultural, global, and professional contexts. They defined the role after a Think Tank 
discussion questioning what kind of engineers we need to educate to meet future challenges. Where Hofland et al. (2015) developed roles based on what industry needs today, Spinks, Silburn, and Birchall (2007) integrated both today's and future challenges, such as globalisation, complexity in technology or sustainability within the role concepts itself.

Unlike Brunhaver et al. (2013) or Gerwel Proches, Chelin, and Rouvrais (2018), none of these three frameworks included a managerial role. In the survey of Spinks, Silburn, and Birchall (2007), company representatives indicated that only 5\% employ graduates (max. 2 years after graduation) in management roles, although graduates were likely to find themselves involved in project management. It seemed likely that there will be some managerial responsibility in all of the roles. This was also observed in the study of Hodgson, Paton, and Cicmil (2011) investigating the role of project manager. Kamp and Klaassen (2016) highlighted the collaboration between the different roles because 'each role cannot realize a technological solution without the other and [each role] is needed to realize integrated solutions for complex problems' (6). The model of Spinks, Silburn, and Birchall (2007) and Hofland et al. (2015) approached their framework differently. They both stated that engineers will more than likely focus on one of the roles, but may be equally able to operate in two or more and they might change roles in the course of their career.

\subsubsection{Stakeholder involvement}

Table 1 (column 9 and 10) shows that the work field or higher education are the stakeholders involved when examining engineering roles or engineering attributes. The work field is mostly rep- resented engineers in the field and alumni $(N=14)$. Three of these studies also involved company representatives and engineering recruitment agencies (Hofland et al. 2015; Lauwers, Bonte, and Vanmaercke 2013; Spinks, Silburn, and Birchall 2007). When higher education is involved $(N=9)$, faculty staff (researchers and staff) were mostly questioned $(N=7)$. Three studies engaged also students (De Norre, Pinxten, and Langie 2016; Gerwel Proches, Chelin, and Rouvrais 2018; Kamp and Klaassen 2016). De Norre, Pinxten, and Langie (2016) included both students' and staff's perspectives in a follow-up study of Hofland et al. (2015) who involved the work field. That means that only one frame- work was validated by both work field and education.

In sum, when excluding engineering roles that are only applicable in specific disciplines or contexts, there seems to be similar categorisations of engineers varying in detail (e.g. consultant vs different types of consultants). However, most of these studies lacked to give clear definitions of the roles and used a typology for other research purposes than developing a framework. A managerial role was often included whereas other studies infer that managerial tasks are essential in all the roles. A convergence occurred between the frameworks of Hofland et al., Kamp and Klaassen and Spinks et al. as the categorisations reflect similar expectations of the work field related to innovation, optimisation and customer needs. Only the first framework was validated by both the educational and work field. As these frameworks were developed to better prepare students for an engineering career, we need to know what the work field expects. At the same time, the frameworks should also be recognised by students and staff as it will be implemented in education.

\subsection{What attributes define the professional roles for early career engineers? (RQ2)}

Twelve studies indicated that different roles required different professional competencies. Ten studies 
did not focus on competencies but on preferences $(N=5)$, expectations $(N=3)$ and value creation ( $N$ $=2$ ) (Table 1, column 11-14). They will be discussed in the following paragraph, after which we examine the results regarding the identifying competencies.

\subsubsection{Preferences $(N=5)$, expectations $(N=3)$ and value creation $(N=2)$}

Eight studies approached the roles by analysing preferences and expectations of engineering students. For example, when comparing job preferences and learning outcomes (De Norre, Pinxten, and Langie 2016); when studying the evolution of students' preferences over time (Gemme and Gingras 2012) or the motivational dimensions of preferences (Bignon and Szajnfarber 2015); or when investigating students' expectations from an engineering career (Gerwel Proches, Chelin, and Rouvrais 2018; Hodgson, Paton, and Cicmil 2011; Kinnunen et al. 2018). These results confirm that preferences might be malleable over time and that developing a range of professional competencies in education is important. They also indicate that students should be equipped with the ability of self-management to make professional choices that are congruent with their personality.

Two studies focused on value creation. Smith, McClelland, and Smith (2017) emphasised on a specific area, namely corporate social responsibility that implies the ethical challenges of an engineer's future work. A more generic approach was the research of Trevelyan and Williams (2018) who determined value creation as a key element to deepen their understanding of engineering practice in different contexts. They identified 14 ways in which engineers create value in the enterprise: from innovation and design, from engineering analysis, from due diligence, from technical collaboration, etc. These findings could support students to understand that all engineering jobs create value to the enterprise and society, also engineers working in roles with few, if any, opportunities for innovation.

\subsubsection{Professional competencies $(N=12)$}

Twelve studies indicated that different roles require a different set of competencies, or at least different importance of the same set of competencies (Table 1, column 11). In an attempt to identify the distinct competencies, we were bounded by the variety of research methods, even when only focusing on the frameworks that described generic roles for early career engineers $(N=6)$. On the one hand, competency lists were drawn from existing literature or other sources (Brunhaver et al. 2013; Hofland et al. 2015; Itani and Srour 2016; Kinoshita, Young, and Knight 2015). Unfortunately, every study administered a particular list. For example, Brunhaver et al. (2013) used a list of 20 competencies based on competencies from ABET and Engineer2020 whereas Hofland et al. (2015) based their research on the 13 learning outcomes of the engineering curriculum of their university. On the other hand, important competencies were retrieved from interviews and discussions with industry (Kamp and Klaassen 2016; Spinks, Silburn, and Birchall 2007). This method resulted in specific engineering competencies that might be a role requirement, like customer awareness, but were not included in for example competency lists based on learning outcomes.

Although these latter studies could provide us with examples of competencies that seemed to vary in importance when applied in different professional roles (Table A1, see Appendix), it should be highlighted that the studies rarely define the competencies in the study and different interpretations of a similar concept might have been occurred. By consequence, the lack of 
definitions hindered further analysis of, for example, the inconsistent results regarding communication skills and teamwork. For example, where communication skills (a very broad concept) were highlighted to vary according to roles, Kamp and Klaassen (2016) and Spinks, Silburn, and Birchall (2007) indicated that communication skills are core competencies for every engineer. Hofland et al. (2015) found the same reasoning regarding teamwork.

In sum, the results confirmed earlier findings that the work field expects early career engineers to have specific (level of) professional competencies in order to be successful in a particular professional role. Due to a variation of competency lists and a lack of definitions, the outcomes of the studies were difficult to compare and only an overview of competencies that might be more important in some roles could be provided (Table Al, see Appendix).

\section{Discussion, limitations and further research}

This study aimed to contribute to the conversation of professional identity development of engineering students by exploring frameworks that categorise professional roles for early career engineers. Such frameworks might be valuable in engineering education to create awareness of the future career as a driving compass for reflection on the future self. To this end, we systematically reviewed literature from 2008 to 2018 and identified 24 relevant papers. In the following discussion, we will expand on the results and suggest future directions for research in career development in engineering education.

\subsection{Professional role concept}

The results in this systematic literature review confirm that literature on professional roles in engineering is scarce and characterised by an inconsistent use of terms. Very few studies defined the concept but there seems to be an agreement that professional roles are more than just jobs or function titles and reflect the expectations of the work field. Different characteristics such as crossdisciplinary or the importance of non-technical competencies seem to support the definition of professional roles we used in this study (Section 2). Hence, in the context of engineering graduates entering the labour market, we may suggest to endorse the concept of professional roles for future research.

\subsection{Professional roles for early career engineers}

In our search for professional roles focused on early career engineers and applicable to multiple engineering disciplines, there seems to be a high degree of convergence between the models of of Hofland et al. (2015), De Norre, Pinxten, and Langie (2016), Kamp and Klaassen (2016), and Spinks, Silburn, and Birchall (2007). The models are simple and clearly describing three to four roles for early career engineers (Table 2). These descriptions indicate that the work field seems to be looking for early career engineers who focus on (1) innovation, (2) optimisation, or (3) customisation. While Kamp and Klaassen identified a separate fourth role to emphasise the diversity and different cultures or contexts, Spinks et al. incorporated future oriented aspects due to globalisation and rapid change within all roles. This high degree of convergence allows us to propose a model with only three professional roles embedded in a broader global or intercultural context 
(Figure 2).

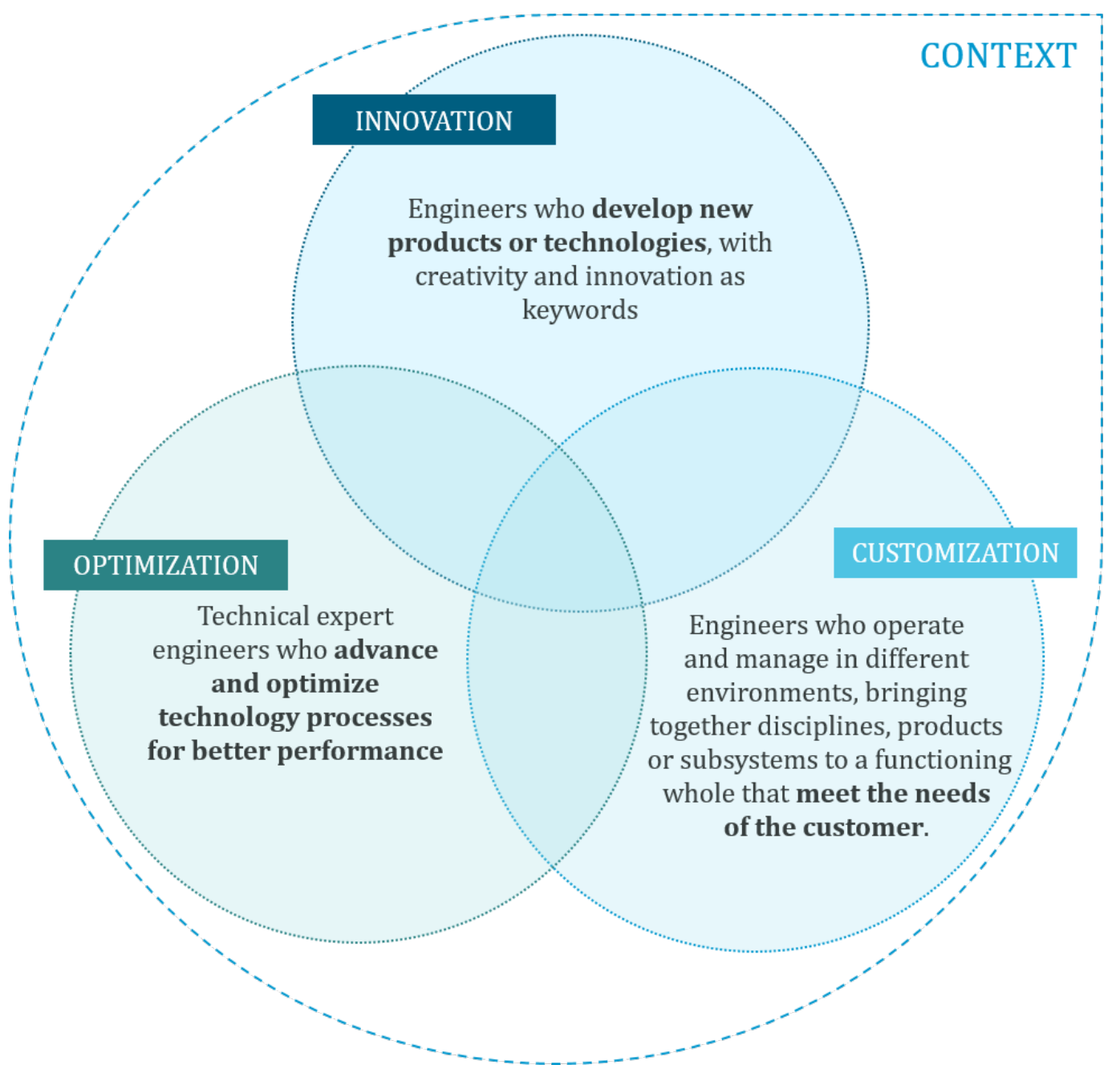

Figure 2. A flexible professional framework defining three professional roles for engineering graduates

Furthermore, Spinks et al. and Hofland et al. and De Norre et al. both stress the flexibility of their framework in similar venn diagram visualisations, allowing to operate in two or more roles or to change roles in the career. This is in line with role models from other fields than engineering that also recognise that in practice several roles are often combined (Frank, Snell, and Sherbino 2015; Lunenberg, Dengerink, and Korthagen 2014; Willnat, Weaver, and Choi 2013). Since there is a general need for a flexible interpretation of the professional roles, the venn diagram, allowing role overlap, is suggested to visualise the proposed threefold model (Figure 2).

The framework of Hofland et al. and De Norre et al. was the only framework validated in a triangulation way by engineers and company representatives, faculty staff and students. A surprising result when addressing the skills and expectations gap.

Further research investigating to what extent the model might evolve or expand can be valuable in the area of career development. The studies included in this review seem to suggest a manager role as a career ladder opportunity (Betz 2014; Hodgson, Paton, and Cicmil 2011; Saunders-Smits and De Graaff 2012) whereas engineering graduates will have some managerial responsibility in all roles (Spinks, Silburn, and Birchall 2007). It can be remarked that the studies which included a separate managerial role for early career engineers did not aim to develop categorisation but 
used predefined categories for other research purposes (Brunhaver et al. 2013; Gerwel Proches, Chelin, and Rouvrais 2018; Itani and Srour 2016; Kinoshita, Young, and Knight 2015; Srour et al. 2013).

Although innovation is a crucial competence in the rapidly evolving world of technology, Trevelyan and Williams (2018) pointed out that most engineers work in roles with few opportunities for innovation. It would be interesting to further investigate how the three roles relate to each other in the work field and whether that might variate in different fields, or in large or small enterprises. Also, the model might be a potential framework for research on the attractiveness of engineering, as the roles make explicit that engineering is not just creating artefacts, processes or systems, but is also involving customer needs. By emphasising this, we might, for example, be able to attract more female students (Bairaktarova and Pilotte 2020). A study on role preference and gender or engineering discipline might contribute to this work.

A limitation of this study is the focus on expectations from the work field. The work field in the included studies were companies or alumni. This excluded non-engineering career possibilities from the beginning or they were excluded due to low sample sizes (Kinnunen et al. 2018; Kinoshita, Young, and Knight 2015). The framework should be interpreted within these boundaries.

\subsection{Role attributes}

Only two studies investigated value creation in engineering. This is in line with previous findings indicating that value creation seldom intrudes on engineering education discourse (Alaksan 2018). Further research on how professional roles can be defined more specifically by creating value in different ways might contribute in enhancing engineering students' reflection on the kind of engineer they want to be.

The majority of the reviewed studies defined roles referring to professional competencies. That might not be surprising as higher education is competency based. The results of this review confirm that different roles require different (levels) of professional competencies, but none of them developed competency profiles that can help educators to devise more precisely activities for students.

In an attempt to identify what competencies might be more required in different roles, we were hindered by the inconsistency of methods and measurements. Many of the reviewed papers failed to address the validity of the measures, which impeded the comparison of outcomes. Different predefined competency list were used to investigate which competencies might be more important. Although some competencies are rather common in engineering education, other competencies are usually not present in the repository of educational resources (e.g. customer orientation, results orientation) (Fernandez-Sanz 2010). In addition, very few studies defined the listed competencies. As research on career development or on professional competencies for engineers has gained a lot of interest in recent years, we might expect accurate definitions of concepts or variables to really move forward to a broader understanding in the field. There is substantial literature on competencies in a work place environment and on the personality dimensions related to specific competency domains, such as The Great Eight Competencies (Bartram 2005). Bartram showed that openness is, for instance, one of the determinants of creating and conceptualising. These studies can offer a solid ground for concepts and definitions that are well known in the repository of career development.

Finally, several studies emphasise the need for differentiation in learning paths towards the 
acquisition of competencies that motivate the students (Kamp and Klaassen 2016; Male, Bush, and Chapman 2011; Spinks, Silburn, and Birchall 2007). Curriculum designers should be aware of the differences in professional roles and maintain flexibility so that graduates know how to choose from a variety of career options. Also, the impact of co-curricular activities on professional competencies should be recognised (Kinoshita, Young, and Knight 2015). Further research is recommended to refine the model and identify the role attributes so that the conceptual framework can evolve into a practical model in engineering education for curriculum designers, tutors, career counsellors, and even student recruiters. As such, the model can be a useful instrument to create professional and self- awareness, so that students can be adequately supported in minding the gap.

\section{Disclosure statement}

No potential conflict of interest was reported by the authors.

\section{Funding}

This work was supported by Erasmus+ Programme of the European Union: [Grant Agreement 575778-EPP-1-2016-1-BEEPPKA2-KA] and is part of the PREFER project (http://www.preferproject.eu/).

\section{Notes on contributors}

Sofie Craps is a doctoral researcher at the KU Leuven Faculty of Engineering Technology (Belgium) and a member of the Study Guidance Research Group of the Leuven Engineering \& Science Education Centre (LESEC). In 2006, she started to work as a recruitment officer at $\mathrm{KU}$ Leuven, focusing on study guidance and science communication and became the communications officer of the KU Leuven Faculty of Engineering Technology. Since then she has provided career guidance to Masters' students and has been teaching communication skills to engineers. Since 2017, she is actively involved in the European PREFER project (Professional Roles and Employability of Future Engineers, www.preferproject.eu).

Maarten Pinxten, Ph.D., is a Research Associate at the Faculty of Engineering Technology of KU Leuven. His main research interests focus on the academic self-concept and educational decision-making. More recently, he investigates starting competences for first-year students in the STEM field and labour market orientation of engineering graduates.

Heidi Knipprath is currently working as a Research Expert at HIVA, the Research Institute for Work and Society of the University of Leuven (KU Leuven), Belgium. She obtained a Ph.D. degree in behavioural and social sciences from the University of Groningen, Netherlands. She is specialized in educational effectiveness and school-to-work transitions.

Greet Langie is since 2012 the vice dean of education of the Faculty of Engineering Technology at KU Leuven (Belgium). She is professor and a board member of SEFI (www.sefi.be) and LESEC (the Leuven Engineering and Science Education Centre (www.set.kuleuven.be/LESEC)). The focus of her research is the transition of STEM-students from secondary education to higher education and the transition from higher education to professional life. She is the promotor of two European projects: readySTEMgo (www.fet.kuleuven.be/readystemgo) and PREFER (www.preferproject.eu).

\section{References}

ABET. 201 7. Criteria for Accrediting Engineering Programs. http://www.abet.org/wp-content/uploads/201 8/02/E001-18-

19- EAC-Criteria-11-29-17.pdf.

Alaksan, E. W. 2018 . "Technology and the Practice of Engineering." In The Engineering-Business Nexus. Symbiosis, Tension and Co-Evolution, edited by S. H. Christensen, B. Delahousse, C. Didier, M. Meganck, and M. Murphy, 261280. Springer Nature. doi:10.1007/978-3-319-99636-3.

Bairaktarova, D. N., and M. K. Pilotte. 2020. "Person or Thing Oriented: A Comparative Study of Individual Differences of First-Year Engineering Students and Practitioners." Journal of Engineering Education, 1-13. doi:10.1002/jee.20309.

Bartram, D. 2005. "The Great Eight Competencies: A Criterion-Centric Approach to Validation." Journal of Applied Psychology90 (6): 1185-1203. doi:10.1037/0021-9010.90.6.1185.

Becker, H. S., and J. W. Carper. 1956. "The Development of Identification with an Occupation." American Journal of Sociology 61. https://www.jstor.org/stable/2773529.

Bennett, D., and S. A. Male. 2017. "An Australian Study of Possible Selves Perceived by Undergraduate Engineering Students." European Journal of Engineering Education 42 (6): 603-61 7. doi:10.1080/03043797.2016.1208149.

Betz, A. 2014. "Evaluation of Personality Traits for a Successful Career of Engineers." Applied Mechanics and Materials 657: 1056-1060. doi:10.4028/www.scientific.net/AMM.657.1056.

Bignon, I., and Z. Szajnfarber. 2015. "Technical Professionals' Identities in the R\&D Context: Beyond the Scientist Versus Engineer Dichotomy." IEEE Transactions on Engineering Management 62 (4): 51 7-528. doi:10.1109/TEM.2015.2455056.

Bimrose, J., S.-A. Barnes, D. Hughes, and M. Orton. 2004. What is Effective Guidance? Evidence from Longitudinal Case 
Studies in England. Coventry. https://warwick.ac.uk/fac/soc/ier/publications/2004/egr2004.pdf.

Borrego, M., M. J. Foster, and J. E. Froyd. 2014. "Systematic Literature Reviews in Engineering Education and Other Developing Interdisciplinary Fields." Journal of Engineering Education 103 (1): 45-76. doi:10.1002/jee.20038.

Bridgstock, R. 2009. "The Graduate Attributes We've Overlooked: Enhancing Graduate Employability Through Career Management Skills." Higher Education Research \& Development 28 (1): 31-44. doi:10.1 080/07294360802444347.

Brown, S. D., and A. Hirschi. 2013. "Personality, Career Development, and Occupational Attainment." In Career Development and Counseling: Putting Theory and Research to Work. 2nd ed., edited by S. D. Brown and R. W. Lent, 299-328. Hoboken, NJ: Wiley \& Sons Inc.

Brunhaver, S., S. K. Gilmartin, M. M. Grau, S. Sheppard, and H. L. Chen. 2013. Not All the Same: A Look at Early Career Engineers Employed in Different Sub-Occupations. Atlanta, GA: American Society for Engineering Education Annual Conference and Exposition.

Brunhaver, S., R. Korte, S. Barley, and S. Sheppard. 2018. "Bridging the Gaps Between Engineering Education and Practice." In US Engineering in the Global Economy, edited by R. B. Freeman and H. Salzman, 129-163. Chicago: NBER: University of Chicago Press.

Burke, C., T. Scurry, J. Blenkinsopp, and K. Graley. 2017. "Critical Perspectives on Graduate Employability." In Graduate Employability in Context, edited by M. Tomlinson and L. Holmes, 113-141. London: Palgrave Macmillan UK. Imprint Palgrave Macmillan. doi:10.1057/978-1-137-57168-7_4.

Chan, C. K. Y., Y. Zhao, and L. Y. Y. Luk. 2017. "A Validated and Reliable Instrument Investigating Engineering Students' Perceptions of Competency in Generic Skills." Journal of Engineering Education 106 (2): 299-325. doi:10.1002/jee. 20165.

Choudhary, N., and B. K. Jesiek. 2015. "Engineering Ph.D. Students' Career Preferences: Levels, Changes, and the Role of Advisors." 2015 IEEE Frontiers in Education Conference (FIE), 1-4. doi:10.1109/FIE.2015.7344217.

De Jager, H., and A. L. Mok. 1999. Grondbeginselen der sociologie: gezichtspunten en begrippen. 11 th ed. Houten: EPN.

De Norre, J., M. Pinxten, and G. Langie. 2016. "Raising Awareness for Professional Roles in the Bachelor's and Master's Programmes in Engineering Technology." Proceedings of the 44th SEFI Annual Conference 2016 - SEFI 2016, 1215. Tampere.

Eccles, J. S. 2011 . "Understanding Educational and Occupational Choices." Journal of Social Issues 67 (3): 644-648. doi:10.1111/j.1471-6402.1994.tb01049.x.

ENAEE. 2015. EUR-ACE ${ }^{\circledR}$ Framework Standards and Guidelines (EAFSG). http://www.enaee.eu/wp-assets-enaee/uploads/ 2017/11/EAFSG-Doc-Full-status-8-Sept-15-on-web-fm.pdf.

Fernandez-Sanz, L. 2010. "Analysis of Non Technical Skills for ICT Profiles." In 5th Iberian Conference on Information Systems and Technologies (Vol. I), edited by Á Rocha, C. F. Sexto, L. P. Reis, and M. P. Cota, 978989. Santiago de Compostela: Information Systems and Technologies (CISTI).

Frank, J. R., L. Snell, and J. Sherbino. 2015. CanMEDS 2015 Physician Competency Framework. Edited by J. R. Frank, L. Snell, and J. Sherbino. Ottawa. http://www.royalcollege.ca/portal/page/portal/rc/canmeds/resources/publications.

Gemme, B., and Y. Gingras. 2012. "Academic Careers for Graduate Students: A Strong Attractor in a Changed Environment." Higher Education 63 (6): 667-683. doi:10.1007/s10734-01 1-9466-3.

Gerwel Proches, C. N., N. Chelin, and S. Rouvrais. 2018. "Think First job! Preferences and Expectations of Engineering Students in a French 'Grande Ecole." European Journal of Engineering Education 43 (2): 309-325. doi:10.1080/ 03043797.2017.1396444.

Gottfredson, G. D., and M. L. Johnstun. 2009. “John Holland's Contributions: A Theory-Ridden Approach to Career Assistance." The Career Development Quarterly 58 (2): 99-107.

Hodgson, D., S. Paton, and S. Cicmil. 2011. "Great Expectations and Hard Times: The Paradoxical Experience of the Engineer as Project Manager." International Journal of Project Management 29 (4): 374-382. doi:10.1016/j.ijproman. 2011.01 .005$.

Hofland, E., M. Pinxten, D. Wauters, and G. Langie. 2015. “'Roles' in the Bachelor's and Master's Programmes in Engineering Technology." Proceedings of the 43rd SEFI Annual Conference 2015 - Diversity in Engineering Education: An Opportunity to Face the New Trends of Engineering, Orléans, France.

Holland, J. L. 1997. Making Vocational Choices: A Theory of Vocational Personalities and Work Environments. Career New Zealand. 3th ed. Lutz: PAR.

IET. 2016. Engineering and Technology Skills and Demand in Industry. Overview of Issues and Trends from 2016 Survey.

https://www.theiet.org/factfiles/education/skills2016-page.cfm?

Itani, M., and I. Srour. 2016. "Engineering Students' Perceptions of Soft Skills, Industry Expectations, and Career Aspirations." Journal of Professional Issues in Engineering Education and Practice 142 (1): 04015005. doi:10.1061/ (ASCE)El.1943-5541.0000247.

Jusoh, M., M. Simun, and S. C. Chong. 2011 . "Expectation Gaps, Job Satisfaction, and Organizational Commitment of Fresh Graduates: Roles of Graduates, Higher Learning Institutions and Employers." Education + Training 53 (6): 515 530. doi: doi:10.1108/00400911111159476.

Kamp, A., and R. Klaassen. 2016. "Impact of Global Forces and Empowering Situations on Engineering Education in 2030." Proceedings of the 12th International CDIO Conference. Turku.

Kinnunen, P., M. Butler, M. Morgan, A. Nylen, A.-K. Peters, J. Sinclair, ... E. Pesonen. 2018 . "Understanding Initial Undergraduate Expectations and Identity in Computing Studies." European Journal of Engineering Education 43 (2): 201-218. doi:10.1080/03043797.2016.1146233.

Kinoshita, T., G. Young, and D. B. Knight. 2015. "Learning After Learning: Perceptions of Engineering Alumni on Skill Development." Proceedings - Frontiers in Education Conference, FIE, 2015-Febru(February). doi:10.1109/FIE.2014. 7044122.

Korte, R., S. Brunhaver, and S. M. Zehr. 2019. "The Socialization of STEM Professionals into STEM Careers: A Study of Newly Hired Engineers." Advances in Developing Human Resources 21 (1): 92-113. doi:10.1177/1523422318814550.

Kubler, B., and P. Forbes. 2004. Student Employability Profiles: Engineering. The Higher Education Academy Engineering Subject Centre. https://www.vampire.bham.ac.uk/externalApplications/careers/PROGRESS/PDFs/employability-guide.pdf.

Lauwers, A., H. Bonte, and R. Vanmaercke. 2013. "Personal Competencies Overview Helping the Graduating Students to Choose a Job." In 41 st SEFI Conference. Leuven: European Society for Engineering Education SEFI.

Lichtenstein, G., H. G. Loshbaugh, B. Claar, H. L. Chen, K. Jackson, and S. D. Sheppard. 2009. "An Engineering Major 
Does Not (Necessarily) an Engineer Make: Career Decision Making." Journal of Engineering Education 98: $227-234$.

Lima, R. M., D. Mesquita, C. Rocha, and M. Rabelo. 2017. "Defining the Industrial and Engineering Management Professional Profile: A Longitudinal Study Based on Job Advertisements." Production 27. doi:10.1590/0103-6513. 229916.

Lunenberg, M., J. Dengerink, and F. Korthagen. 2014. The Professional Teacher Educator. Roles, Behaviour, and Professional Development of Teacher Educators. Professional Learning (Vol. 13). Rotterdam: Sense Publishers. doi:10.1017/ СBO9781107415324.004.

Male, S. A., M. B. Bush, and E. S. Chapman. 2011 . "Understanding Generic Engineering Competencies." Australasian Journal of Engineering Education 17 (3): 147-156. doi:10.1080/22054952.2011.11464064.

Matusovich, H., R. Streveler, R. Miller, and B. Olds. 2009. "I'm Graduating This Year! So What IS an Engineer Anyway?" Proceedings of the 2009 American Society for Engineering Education Conference, Austin, TX.

Medina, L. A., S. Sierra, M. González, M. Rios, N. Oquendo, C. Quijano, and K. Gómez. 2018. "RealTimePC: Case Studies of the Roles of an Industrial Engineer." In IISE Annual Conference and Expo, edited by K. Barker, D. Berry, and C. Rainwater, 1683-1688. Orlando, FL.

Morelock, J. R. 2017. "A Systematic Literature Review of Engineering Identity: Definitions, Factors, and Interventions Affecting Development, and Means of Measurement." European Journal of Engineering Education 42 (6): 1240-1262. doi:10.1080/03043797.2017.1287664.

Mourshed, M., J. Patel, and K. Suder. 2014. Education to Employment: Getting Europe's Youth into Work. https:// www.mckinsey.com/ /media/mckinsey/industries/social\%20sector/our\%20insights/converting\%20education\%20to \%20employment\%20in\%20europe/education\%20to\%20employment\%20getting\%20europes\%20youth\%20into\% 20work\%20full\%20report.ashx.

Murphy, M., K. Hawwash, M. Vigild, and X. Fouger. 2016. Developing Graduate Engineering Skills. Brussels. http:// sefibenvwh.cluster023.hosting.ovh.net/wp-content/uploads/2017/07/POsition-Paper-on-Engineering-Skills.pdf.

National Academy of Engineering. 2004. The Engineer of 2020: Visions of Engineering in the New Century. National Academies Press. doi:10.17226/10999.

National Academy of Engineering. 2018. Understanding the Educational and Career Pathways of Engineers. Understanding the Educational and Career Pathways of Engineers. Washington, DC: National Academies Press. doi: $10.17226 / 25284$.

Nilsson, S. 2010. "Enhancing Individual Employability: The Perspective of Engineering Graduates." Education + Training 52 (6/7): 540-551. doi:10.1108/00400911011068487.

Oyserman, D., D. Bybee, K. Terry, and T. Hart-Johnson. 2004. "Possible Selves as Roadmaps." Journal of Research in Personality 38: 130-149. doi:10.1016/S0092-6566(03)00057-6.

Paulsen, J. E. 2011. "Ethics of Caring and Professional Roles." Nursing Ethics 18 (2): 201-208. doi:10.1177/ 0969733010392302.

Petticrew, M., and H. Roberts. 2006. Systematic Reviews in the Social Sciences: A Practical Guide. 1 st ed. Oxford: Blackwell Publishing Ltd.

Saunders-Smits, G., and E. De Graaff. 2012. "Assessment of Curriculum Quality Through Alumni Research." European Journal of Engineering Education 37 (2): 133-142. doi:10.1080/03043797.2012.665847.

Sinche, M., R. L. Layton, P. D. Brandt, A. B. O'Connell, J. D. Hall, A. M. Freeman, and P. J. Brennwald. 2017. "An EvidenceBased Evaluation of Transferrable Skills and Job Satisfaction for Science PhDs." PloS One 12 (9): e0185023. doi:10.1371/ journal.pone.0185023.

Smith, J. M., C. J. McClelland, and N. M. Smith. 2017. "Engineering Students' Views of Corporate Social Responsibility: A Case Study from Petroleum Engineering." Science and Engineering Ethics 23: 1775-1 790. doi:10.1007/s 1 1948-016-9859$x$.

Spinks, N., N. L. J. Silburn, and D. W. Birchall. 2007. "Making It All Work: The Engineering Graduate of the Future, a UK Perspective." European Journal of Engineering Education 32 (3): 325-335. doi:10.1080/03043790701278573.

Srour, I., M.-A. Abdul-Malak, M. Itani, A. Bakshan, and Y. Sidani. 2013. "Career Planning and Progression for Engineering Management Graduates: An Exploratory Study." Engineering Management Journal 25 (3): 85-100. doi:10.1080/ 10429247.2013.11431985.

Tomlinson, M. 2007. "Graduate Employability and Student Attitudes and Orientations to the Labour Market." Journal of Education and Work 20 (4): 285-304. doi:10.1080/13639080701650164.

Trevelyan, J., and B. Williams. 2018 . "Value Creation in the Engineering Enterprise: An Educational Perspective." European Journal of Engineering Education. doi:10.1080/03043797.2017.1421905.

Tymon, A. 2013. "The Student Perspective on Employability." Studies in Higher Education 38 (6): 841-856. doi:10.1080/ 03075079.2011.604408.

Van der Heijden, B. I. J. M., J. G. Brinkman, and W. E. During. 2009. "Careers of Entrepreneurial Engineers: An Empirical Study in Knowledge-Intensive Firms in the Netherlands." Journal of Applied Management and Entrepreneurship 14 (3): 49.

Watson, J. M., and P. F. Meiksins. 1991. "What Do Engineers Want? Work Values, Job Rewards, and Job Satisfaction." Science, Technology \& Human Values 16 (2): 140-172. doi:10.1177/016224399101600202.

Wilcox, L. F. 2015. "Identifying Roles in University-Industry Research Partnerships." 122 nd ASEE Annual Conference \& Exposition, Seattle, Washington.

Willnat, L., D. H. Weaver, and J. Choi. 2013. "The Global Journalist in the Twenty-First Century. A Cross-National Study of Journalistic Competencies." Journalism Practice 7 (2): 163-183. doi:10.1080/17512786.2012.753210.

Yorke, M., and P. T. Knight. 2006. Embedding Employability into the Curriculum. Learning and Employability Series 1. York: The Higher Education Academy. 


\section{Appendix}

Table A1. Identifying competencies per role

\begin{tabular}{|c|c|c|c|c|c|c|c|c|c|}
\hline Study & Sample & Method & $\begin{array}{l}\text { Competencie } \\
\text { s retrieved } \\
\text { from... }\end{array}$ & Measure & Role 1 & Role 2 & Role 3 & Role 4 & Role 5 \\
\hline $\begin{array}{l}\text { Brunhaver } \\
\text { et al. } \\
\text { (2013) }\end{array}$ & $\begin{array}{l}\mathrm{N}=543 \\
\text { engineers } \\
\text { (max. } 4 \text { years } \\
\text { of experience) }\end{array}$ & Questionnaire & $\begin{array}{l}20 \\
\text { competencies } \\
\text { from ABET } \\
\text { Criterion } \\
2011-2012 \\
\text { and } \\
\text { Engineering } \\
2020\end{array}$ & $\begin{array}{l}\text { Perception } \\
\text { about } \\
\text { importance of } \\
\text { competencies in } \\
\text { the current } \\
\text { work }\end{array}$ & Practitioners & \begin{tabular}{|l|} 
Managers \\
Business knowledge \\
Leadership \\
Management skills \\
Engineering \\
techniques/tools* \\
Communication \\
Managing uncertainty
\end{tabular} & $\begin{array}{l}\text { Consultants } \\
\text { Design } \\
\text { Planning and } \\
\text { conducting } \\
\text { experiments* }\end{array}$ & & \\
\hline $\begin{array}{l}\text { Hofland et } \\
\text { al. (2015) }\end{array}$ & $\begin{array}{l}\mathrm{N}=5 \text { HR } \\
\text { managers } \\
\mathrm{N}=121 \\
\text { company } \\
\text { representative } \\
\text { s working with } \\
\text { engineers }\end{array}$ & \begin{tabular}{|l|} 
Mixed \\
method: \\
interviews and \\
survey
\end{tabular} & $\begin{array}{l}13 \text { KU Leuven } \\
\text { Engineering } \\
\text { Technology } \\
\text { learning } \\
\text { outcomes } \\
2014-2015\end{array}$ & $\begin{array}{l}\text { Perception } \\
\text { about } \\
\text { importance of } \\
\text { competencies in } \\
\text { the professional } \\
\text { roles }\end{array}$ & $\begin{array}{l}\text { Operational } \\
\text { Excellence } \\
\text { Problem analysing } \\
\text { and solving } \\
\text { Operationalisation } \\
\text { Basic technical } \\
\text { knowledge } \\
\text { Basic scientific } \\
\text { knowledge }\end{array}$ & $\begin{array}{l}\text { Product Leadership } \\
\text { Design and } \\
\text { development } \\
\text { Basic scientific } \\
\text { knowledge } \\
\text { Specialised } \\
\text { technological } \\
\text { knowledge }\end{array}$ & $\begin{array}{l}\text { Customer Intimacy } \\
\text { Professionalism } \\
\text { Entrepreneurship } \\
\text { (taking initiative and } \\
\text { sense for business) } \\
\text { Communication } \\
\text { Basic scientific } \\
\text { knowledge* } \\
\text { Ethical responsibility }\end{array}$ & & \\
\hline $\begin{array}{l}\text { Kamp \& } \\
\text { Klaassen } \\
(2016)\end{array}$ & $\begin{array}{l}\mathrm{N}=12 \text { full, } \\
\text { associate and } \\
\text { assistant } \\
\text { professors, } \\
\text { senior } \\
\text { lecturers, } \\
\text { programme } \\
\text { directors, } \\
\text { members of } \\
\text { the } \\
\text { valorisation } \\
\text { centre and } \\
\text { student bodies } \\
\text { from all } \\
\text { disciplines of } \\
\text { the institution, }\end{array}$ & $\begin{array}{l}\text { Design } \\
\text { thinking }\end{array}$ & / & $\begin{array}{l}\text { Unravel the } \\
\text { capabilities and } \\
\text { knowledge the } \\
\text { future engineer } \\
\text { in different } \\
\text { scenario's }\end{array}$ & $\begin{array}{l}\text { Specialist } \\
\text { Fundamental science } \\
\text { knowledge } \\
\text { In-depth disciplinary } \\
\text { knowledge } \\
\text { Research and } \\
\text { experimentation } \\
\text { skills } \\
\text { Problem defining } \\
\text { skills } \\
\text { Critical thinking skills } \\
\text { Analytic engineering } \\
\text { mind-set } \\
\text { Independent } \\
\text { Curious } \\
\text { Language (e.g., }\end{array}$ & $\begin{array}{l}\text { Front-end Innovator } \\
\text { Product knowledge } \\
\text { and design process } \\
\text { Customer and market } \\
\text { trends knowledge } \\
\text { Business economics } \\
\text { knowledge } \\
\text { Critical questioning } \\
\text { skills } \\
\text { Entrepreneurial skills } \\
\text { Innovative skills } \\
\text { Open-minded } \\
\text { Empathic } \\
\text { Explorative } \\
\text { Creative risk-taking } \\
\text { Language (e.g., }\end{array}$ & $\begin{array}{l}\text { System Integrator } \\
\text { Broad technical } \\
\text { knowledge } \\
\text { Complex systems } \\
\text { knowledge } \\
\text { Understanding } \\
\text { engineering } \\
\text { languages } \\
\text { System thinking skills } \\
\text { Structured project } \\
\text { skills } \\
\text { Integration skills } \\
\text { Object oriented } \\
\text { attitude } \\
\text { Pragmatic } \\
\text { Organised }\end{array}$ & $\begin{array}{l}\text { Contextual } \\
\text { Engineer } \\
\text { Role of the } \\
\text { environment } \\
\text { knowledge } \\
\text { Cultural, legal and } \\
\text { political knowledge } \\
\text { Broad technical } \\
\text { knowledge } \\
\text { Networking skills } \\
\text { Leadership skills } \\
\text { Conflict and } \\
\text { negotiation skills } \\
\text { Resilient } \\
\text { Visionary } \\
\text { Perseverance } \\
\text { Language (e.g., }\end{array}$ & \\
\hline
\end{tabular}




\begin{tabular}{|c|c|c|c|c|c|c|c|c|c|}
\hline \multirow[b]{2}{*}{$\begin{array}{l}\text { Spinks et } \\
\text { al. (2007) }\end{array}$} & \multirow[b]{2}{*}{$\begin{array}{l}\mathrm{N}=30 \\
\text { (experienced } \\
\text { industry } \\
\text { practitioners) } \\
\mathrm{N}=28 \text { (recent } \\
\text { engineering } \\
\text { graduates) } \\
\mathrm{N}=444 \\
\text { (engineering } \\
\text { companies) }\end{array}$} & \multirow[b]{2}{*}{$\begin{array}{l}\text { Mixed } \\
\text { method: in- } \\
\text { depth expert } \\
\text { interviews, } \\
\text { focus groups, } \\
\text { and a large- } \\
\text { scale survey }\end{array}$} & \multirow[b]{2}{*}{\begin{tabular}{l|}
6 skills \\
presented in \\
the survey, \\
based in \\
results of \\
interviews and \\
focus groups
\end{tabular}} & \multirow[b]{2}{*}{$\begin{array}{l}\text { Higher level } \\
\text { synthesis of the } \\
\text { findings of the } \\
\text { research into a } \\
\text { depiction of the } \\
\text { engineering } \\
\text { graduate of the } \\
\text { future }\end{array}$} & \begin{tabular}{|l} 
communication skills, \\
design literacy ...)
\end{tabular} & $\begin{array}{l}\text { communication skills, } \\
\text { design literacy ...) }\end{array}$ & \begin{tabular}{|l|} 
Responsible \\
Language (e.g., \\
communication skills, \\
design literacy ...)
\end{tabular} & $\begin{array}{l}\text { communication } \\
\text { skills, design } \\
\text { literacy ...) }\end{array}$ & \\
\hline & & & & & $\begin{array}{l}\text { Specialist } \\
\text { Technical expertise }\end{array}$ & \begin{tabular}{l|} 
Change agent \\
Creativity \\
Innovation \\
Leadership \\
Managing uncertainty
\end{tabular} & $\begin{array}{l}\text { Integrator } \\
\text { System thinking } \\
\text { perspective } \\
\text { (interdisciplinary } \\
\text { thinking, commercial } \\
\text { awareness, business } \\
\text { awareness) }\end{array}$ & & \\
\hline \multirow{2}{*}{$\begin{array}{l}\text { Itani et al. } \\
\text { (2016) }\end{array}$} & \multirow{2}{*}{$\begin{array}{l}\mathrm{N}=306 \text { senior } \\
\text { engineering } \\
\text { students }\end{array}$} & \multirow[t]{2}{*}{ Questionnaire } & \multirow[b]{2}{*}{$\begin{array}{l}49 \text { items (5 } \\
\text { questions) } \\
\text { based on } \\
\text { literature } \\
\text { (Rynes (2017), } \\
\text { Meier et al. } \\
\text { (2000), ABET } \\
\text { (2011), Lang } \\
\text { et al. (1999)) }\end{array}$} & \multirow[b]{2}{*}{$\begin{array}{l}\text { Perceptions of } \\
\text { soft skills } \\
\text { between } \\
\text { students with } \\
\text { technical (TA) } \\
\text { and non- } \\
\text { technical career } \\
\text { aspirations } \\
\text { (NTA)** }\end{array}$} & \multicolumn{2}{|c|}{ Technical career aspirations } & \multicolumn{3}{|c|}{ Non-technical career aspirations } \\
\hline & & & & & \multicolumn{2}{|c|}{$\begin{array}{l}\text { Engaging in self-development and } \\
\text { continuous learning involving technical } \\
\text { knowledge }\end{array}$} & \multicolumn{3}{|c|}{$\begin{array}{l}\text { Communication and presentation skills } \\
\text { Basic accounting/finance and basic marketing } \\
\text { (Project) management } \\
\text { Creativity and optimism } \\
\text { Risk-taking propensity }\end{array}$} \\
\hline $\begin{array}{l}\text { Kinoshita } \\
\text { et al. } \\
\text { (2014) }\end{array}$ & $\begin{array}{l}\mathrm{N}=1339 \\
\text { alumni } \\
\text { engineers } \\
\text { (max. } 3 \text { years } \\
\text { of experience) }\end{array}$ & Questionnaire & $\begin{array}{l}4 \text { skills: 1) } \\
\text { engineering } \\
\text { design, 2) } \\
\text { teamwork, 3) } \\
\text { communicatio } \\
\text { n, and 4) } \\
\text { leadership }\end{array}$ & $\begin{array}{l}\text { Relative to the } \\
\text { technical job } \\
\text { function } \\
\text { category (the } \\
\text { reference): } \\
\begin{array}{l}\text { 1. Perception of } \\
\text { senior-year } \\
\text { skills }\end{array}\end{array}$ & Technical & \begin{tabular}{l|} 
Design skills \\
$\begin{array}{l}\text { Communication skills } \\
\text { Leadership skills }\end{array}$
\end{tabular} & Consultant & Non-technical & Other \\
\hline
\end{tabular}




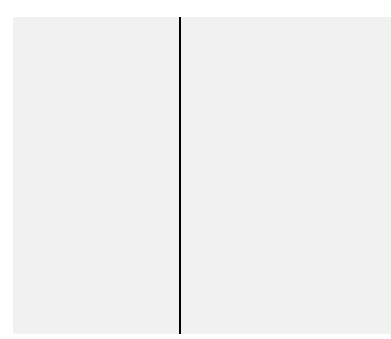

$$
\begin{array}{|l|}
\text { 2. Perception of } \\
\text { three years } \\
\text { post-graduation } \\
\text { skills, relative to } \\
\text { the technical } \\
\text { job function } \\
\text { category (the } \\
\text { reference) }
\end{array}
$$

* significantly less important
** Itani et al. (2016) excluded th

$\because *$ Itani et al. (2016) excluded the category 'job rotation program' in this part of the research due to position will be determined at a later stage

\begin{tabular}{|l|l|l|}
$\begin{array}{l}\text { Design skills* } \\
\text { Leadership skills }\end{array}$ & Communication skills & $\begin{array}{l}\text { Design skills* } \\
\text { Communication } \\
\text { skills }\end{array}$ \\
& &
\end{tabular}

Design skills

Communication

skills*

Teamwork* 